\title{
OPTIMALISASI PERAN DEWAN PENGAWAS SYARIAH DALAM
}

\section{PELAKSANAAN GOOD CORPORATE GOVERNANCE DI BPRS HARUM HIKMAHNUGRAHA}

\author{
Biki Zulfikri Rahmat \\ Prodi Ekonomi Syariah Universitas Siliwangi \\ Jalan Siliwangi No.24, Kahuripan, Tasikimalaya. Indonesia \\ bikizulfikrirahmat@unsil.ac.id
}

\begin{abstract}
Abstrak
Resiko terbesar menghadapi sistem keuangan global bukanlah kesalahan tentang kemampuan menciptakan laba, tetapi yang lebih penting adalah kehilangan kepercayaan dan kredibilitas operasional. CG adalah mengontrol secara keseluruhan yang ditetapkan secara internal dan eksternal atas manajemen untuk melindungi semua stakeholders. Tujuan penelitian untuk mengetahui bagaimana peran DPS melaksanakan GCG pada bank syariah, serta pengaruh pelaksanaan GCG terhadap tingkat kepercayaan masyarakat pada BPRS Harum Hikmahnugraha.Metode yang digunakan dalam penelitian adalah metode deskriftif kualitatif. Hasil penelitian menunjukkan GCG bank syariah berbeda dengan yang dilaksanakan bank konvensional dan memiliki karakterisitik terkait dengan operasional. Perbedaan terletak pada shari'ah compliance pada aktivitas bank syariah. Sehingga dapat disimpulkan DPS sangat berperan dalam pelaksanaan GCG di BPRS Harum Hikmahnugraha terutama aspek pemenuhan prinsip syariah,DPS adalah pihak yang memastikan dan mengawasi kesesuaian operasional dan produk bank terhadap prinsip syariah.Dilihat dari reaksi deposan ketika mengetahui bank tidak berkinerja dengan baik dan tidak sesuai dengan prinsip syariah, deposan akan mengalihkan dananya.
\end{abstract}

Kata Kunci :GCG, Bank Syariah, DPS.

The biggest risk facing the global financial system is not the fault of the ability to make a profit, but more important is the loss of trust and credibility operational. CG is the control that is set internally and externally over management to protect all stakeholders. The aim of research to find out how the role of DPS to implement corporate governance in Islamic banks, as well as the influence of GCG implementation on the level of public confidence in BPRS Harum Hikmahnugraha.Metode used in the study is a qualitative descriptive method. The results showed GCG different Islamic banks with conventional banks implemented and have the characteristics associated with the operation.The difference lies in the shari'ah compliance on the activities of sharia banks. It can be concluded DPS was instrumental in the implementation of GCG in BPRS Harum Hikmahnugraha especially aspects of fulfillment of sharia principles,DPS is the party that ensure and oversee operations and product conformity to the principles syariah.Dilihat bank from depositors reaction when knowing the bank is not performing well and not in accordance with Sharia principles, depositors will divert their funds.

Keywords: GCG, Islamic Banks, DPS. 


\section{PENDAHULUAN}

Serangkaian krisis yang melanda sistem keuangan internasional selama beberapa dekade terakhir ini menuntut terbentuknya suatu perubahan rancangan sistem yang baru. Berbagai pendekatan dalam diskusi dan Forum Internasional telah menemukan suatu titik kesimpulan, bahwa karakteristik utama dari perancangan sistem yang baru tersebut adalah pengembangan $\mathrm{CG}$ yang didukung oleh regulasi dan pengawasan dengan prinsip kehati-hatian (Umer \& Ahmed, 2008)

Untuk memastikan terpenuhinya semua tujuan tersebut, serta untuk menciptakan kesehatan dan stabilitas sistem keuangan, perhatian terhadap peningkatan CG merupakan syarat mutlak yang harus dipenuhi (Puspitasari, 2009).

(Cadbury, 2001) menegaskan bahwa oleh karena sifat kegiatan usaha bank yang menghimpun dana dari masyarakat dan disalurkan dalam berbagai bentuk kegiatan terutama pembiayaan dan investasi maka sangatlah diperlukan suatu upaya perlindungan yang memadai agar fungsi penting untuk mendukung pembangunan ekonomi ini dapat berjalan dengan sebaik-baiknya. Resiko yang dihadapi oleh bank harus dipantau dengan suatu mekanisme check and balance yang memadai agar dapat menjaga kepercayaan pihak-pihak yang sangat berkepentingan dengan fungsi perbankan. Hal-hal yang terkait dengan mekanisme check and balance inilah yang menjadi fokus perhatian dari sistem CG.

Pada bank konvensional system governance yang baik antara lain dapat dikembangkan dengan memperjelas fungsi,kewenangan dan pola hubungan antara pemegang saham (Dewan Komisaris) dan manajemen bank. Sementara itu struktur governance pada bank syariah akan melibatkan lebih banyak pihak karena adanya karakteristik khusus dari bank syariah yaitu kewajiban untuk mematuhi prinsip-prinsip syariah (shari'ah compliance) dalam menjalankan bisnisnya. Karena stakeholders terpenting yang paling utama dalam sistem keuangan Islam adalah Islam itu sendiri. Jika bank tidak mampu menunjukkan kinerja dengan baik, orang akan beranggapan bahwa sistem Islam tidak selaras dengan dunia modern dan Islam akan disalahkan karena kinerja bank syariah yang jelek tersebut, meskipun Islam sendiri tidaklah demikian.

Keharusan tampilnya bank syariah sebagai pionir penegakan GCG dibanding bank konvensional, menurut (Mervin, Latifa, \& Al-Haod, 2005) karena permasalahan governance dalam bank syariah ternyata berbeda dengan bank konvensional. Pertama, bank syariah 
Amwaluna: Jurnal Ekonomi dan Keuangan Syariah Vol. 1 No.2 (Juli, 2017), 276-296

Online ISSN : 2540-8402 | Print ISSN : 2540-8399

memiliki kewajiban untuk mematuhi prinsip-prinsip

syariah

(shari'ah compliance) dalam menjalankan bisnisnya. Karenanya, DPS memainkan peran yang penting dalam governance structure perbankan syariah. Kedua, karena potensi terjadinya information asymetry tinggi bagi perbankan syariah maka permasalahan agency theory menjadi sangat relevan. Hal ini terkait dengan permasalahan tingkat akuntabilitas dan transparansi penggunaan dana nasabah dan pemegang saham. Karenanya, permasalahan keterwakilan investment account holders dalam mekanisme GCG menjadi masalah strategis yang mesti mendapat perhatian dari bank syariah. Ketiga, dari perspektif budaya korporasi, perbankan syariah semestinya melakukan transformasi budaya dimana nilai-nilai etika bisnis Islami menjadi karakter yang inheren dalam praktik bisnis perbankan syariah (Promono, 2008).

Kondisi diatas menuntut bank syariah memberikan jaminan mengenai kesesuaian syariah untuk seluruh aktivitasnya ataupun prinsip-prinsip prudensial yang dibutuhkan dari sebuah bank, disamping pelayanan bagi konsumen. Berdasarkan Peraturan Bank Indonesia Nomor 11/33/PBI/2009 pelaksanaan GCG harus diwujudkan dalam tugas dan tanggung jawab DPS. Apabila kinerja DPS berjalan dengan baik diharapkan pelaksanaan GCG atau tata kelola bank syariah tersebut baik dan konsisten. Namun, peran pengawasan yang dilakukan DPS saat ini masih belum optimal.

Suatu kenyataan bahwa banyak anggota DPS yang diangkat disebabkan oleh kharisma dan kepopulerannya di tengah masyarakat, bukan karena kompetensi keilmuannya di bidang ekonomi dan perbankan syariah. Anggota DPS semestinya selain memahami fiqih muamalah juga memahami ilmu yang terkait dengan perbankan syariah, seperti ilmu ekonomi moneter. Dengan demikian tidak ada lagi ulama yang menyamakan margin jual beli murabahah dengan bunga. Selain itu DPS datang sekali dalam sebulan atau sekali dalam seminggu bahkan ada yang berbulan-bulan tidak datang ke bank syariah yang semestinya diawasinya. Pengawasan model demikian jelas tidak signifikan dalam pengawasan perbankan syariah, karena peran DPS ditempatkan hanya sebagai penasehat yang boleh datang pada waktu-waktu tertentu saja, akibatnya pengawasan dan peranperan strategis lainnya sangat tidak optimal.Oleh karena itu, tak mengherankan jika masih banyak praktek 
perbankan syariah yang menyimpang dari ketentuan syariah Islam. Inilah realitas yang terjadi di lembaga perbankan syariah di Indonesia saat ini. Maka tidak heran,jika masih banyak bank syariah yang 'menyimpang' dari prinsip syariah.

Melihat fenomena yang terjadi diatas terkait dengan beberapa penyimpangan-penyimpangan terhadap ketentuan-ketentuan prinsip syariah di bank syariah dan urgennya pelaksanaan GCG di bank syariah terutama dalam hal pemenuhan prinsip-prinsip syariah. Maka penulis tertarik untuk melakukan sebuah penelitian dengan mengambil judul “OptimalisasiPeran Dewan Pengawas Syariah Dalam Pelaksanaan Good Corporate Governance Di BPRS Harum Hikmah nugraha”.

Metode penelitian yang digunakan adalah penelitian deskriptif analisis, yaitu penelitian yang menggambarkan sifat sesuatu yang sedang berlangsung pada saat riset dilakukan dan memeriksa sebabsebab dari suatu gejala tertentu, secara rinci mengenai suatu obyek tertentu selama kurun waktu tertentu dengan cukup mendalam dan menyeluruh. Dalam penelitian ini akan di fokuskan rumusan masalah dan tujuan penelitiannya adalah untuk melihat tugas dan peran DPS dalam pelaksanaan GCG terutama aspek shari'ah compliance, serta melihat pengaruh dari penerapan GCG terutama aspek shari'ah compliance terhadap tingkat kepercayaan masyarakat pada bank syariah (BPRS Harum Hikmah nugraha) dengan metode deskriptif analisis, sehingga untuk menganalisis data dengan cara mendeskripsikan atau menggambarkan data yang telah terkumpul sebagaimana adanya tanpa bermaksud membuat kesimpulan yang berlaku untuk umum atau generalisasi. Data yang diperoleh peneliti didapat dari hasil observasi (pengamatan), interview (wawancara), kuesioner (angket), triangulasi, dokumentasi dan gabungan keempatnya, dengan sumber primer (jurnal, buku, tesis, disertasi, melakukan wawancara dengan DPS, direksi, beberapa staff dan nasabah, dan sumber sekunder (majalah, website, laporan-laporan GCG serta literatur yang relevan dengan masalah penelitian). AdapunAnalisa data kualitatif adalah bersifat induktif, yaitu suatu analisis berdasarkan data yang diperoleh, selanjutnya dikembangkan menjadi hipotesis. Analisis data kualitatif dilakukan secara interaktif dan berlangsung secara terus menerus sampai tuntas, sehingga datanya jenuh. Ukuran kejenuhan data ditandai dengan tidak diperolehnya lagi data atau informasi baru. Aktivitas dalam analisis meliputi reduksi data (data reduction), penyajian data(data display) 
Amwaluna: Jurnal Ekonomi dan Keuangan Syariah Vol. 1 No.2 (Juli, 2017), 276-296

Online ISSN : 2540-8402 | Print ISSN : 2540-8399

serta penarikan kesimpulan danverifikasi (conclusion drawing/verification). (A, 2010).

\section{PEMbahasan}

Seiring dengan perkembangan industri perbankan syariah yang ditandai dengan semakin beragamnya produk perbankan syariah dan bertambahnya jaringan pelayanan perbankan syariah, maka GCG pada industri perbankan syariah menjadi semakin penting untuk dilaksanakan. Pelaksanaan GCG pada industri perbankan syariah harus berlandaskan pada lima prinsip dasar. Pertama, transparansi (transparency), yaitu keterbukaan dalam mengemukakan informasi yang material dan relevan serta keterbukaan dalam proses pengambilan keputusan. Kedua, akuntabilitas (accountability) yaitu kejelasan fungsi dan pelaksanaan pertanggungjawaban organ bank sehingga pengelolaannya berjalan secara efektif. Ketiga, pertanggungjawaban (responsibility) yaitu kesesuaian pengelolaan bank dengan peraturan perundang-undangan yang berlaku dan prinsip-prinsip pengelolaan bank yang sehat. Keempat, profesional (professional) yaitu memiliki kompetensi, mampu bertindak obyektif dan bebas dari pengaruh/tekanan dari pihak manapun (independen) serta memiliki komitmen yang tinggi untuk mengembangkan bank syariah. Kelima, kewajaran (fairness) yaitu keadilan dan kesetaraan dalam memenuhi hak-hak stakeholdersberdasarkan perjanjian dan peraturan perundangundangan yang berlaku. (Khafid, 2012).

Dalam rangka menerapkan kelima prinsip dasar tersebut, bank wajib berpedoman pada berbagai ketentuan dan persyaratan yang terkait dengan pelaksanaan GCG.Selain itu dalam pelaksanaan GCG, industri perbankan syariah juga harus memenuhi prinsip syariah (sharia compliance). Ketidaksesuaian tata kelola bank dengan prinsip syariah akan berpotensi menimbulkan berbagai risiko terutama risiko reputasi bagi industri perbankan syariah. Pelaksanaan GCG perbankan syariah tidak hanya dimaksudkan untuk memperoleh pengelolaan bank yang sesuai dengan lima prinsip dasar dan sesuai dengan prinsip syariah, akan tetapi juga ditujukkan untuk kepentingan yang lebih luas. Kepentingan ini antara lain adalah untuk melindungi kepentingan stakeholders dan meningkatkan kepatuhan terhadap peraturan perundang-undangan yang berlaku serta nilai etika yang berlaku secara umum pada industri perbankan syariah. 
Berdasarkan Peraturan Bank Indonesia Nomor 11/33/PBI/2009 pelaksanaan GCG mesti diwujudkan dalam tugas dan tanggung jawab DPS serta penerapan fungsi kepatuhan audit intern dan audit ekstern. Pemain kunci yang khas dalam pelaksanaan GCG dalam rangka pemenuhan prinsip syariah, yaitu Dewan Pengawas Syariah (DPS). DPS adalah pihak yang melakukan audit syariah selain audit yang lazim untuk memastikan pelaksanaan GCG dalam pemenuhan prinsip syariah (sharia compliance) di bank syariah. DPS adalah pihak yang memastikan dan mengawasi kesesuaian operasional dan produk bank terhadap prinsip syariah yang termasuk dalam Fatwa Dewan Syariah Nasional (DSN).

\section{A. Hasil Penelitian dan Analisis}

\section{Profil DPS BPRS Harum}

\section{Hikmahnugraha}

Berdasarkan hasil keputusan RUPS

Tahunan tanggal 21 Februari 2013 M, ditetapkan bahwa susunan DPS adalah sebanyak 3 (tiga) orang, yaitu: 1). Pendidikan terakhir adalah S1 Akhwalus Syahsiyyah Fakultas Syariah UINSGD Bandung. 2). Berpendidikan S1 Ilmu alQur'an Perguruan Tinggi Ilmu Qur'an Jakarta. 3). Pendidikan terakhirnya adalah S1 PAI STAI Siliwangi Garut.

Dilihat dari latar belakang pendidikannya, penulis mengasumsikan bahwa ketiganya belum cukup memiliki pengetahuan dan pemahaman yang memadai di bidang keuangan dan perbankan syariah. Dilihat dari aspek pengalaman atau aktivitas keseharian pun para DPS kurang memiliki pengalaman dan reputasi di bidang keuangan dan perbankan syariah. Padahal semestinya yang menjadi DPS di bank syariah memiliki kompetensi keilmuan dan reputasi di bidang keuangan dan perbankan syariah guna mengefektifkan tugasnya untuk mengawasi dan memastikan operasional BPRS Harum Hikmah nugraha senantiasa sesuai dengan Fatwa DSN-MUI maupun ketentuan syariah lainnya. Anggota DPS pun selain dituntut memahami fiqih muamalah juga memahami ilmu yang terkait dengan perbankan syariah, seperti ilmu ekonomi moneter.

Hal ini sesuai dengan yang dikemukakan di latar belakang masalah bahwa masih banyak anggota DPS yang diangkat disebabkan oleh kharisma dan kepopulerannya di tengah masyarakat, bukan karena kompetensi keilmuannya di bidang ekonomi dan perbankan syariah. Termasuk BPRS Harum Hikmah nugraha pengangkatan DPS bukan dikarenakan kompetensi keilmuannya di bidang keuangan dan perbankan syariah, tetapi lebih kepada merupakan bagian dari 
Amwaluna: Jurnal Ekonomi dan Keuangan Syariah Vol. 1 No.2 (Juli, 2017), 276-296

Online ISSN : 2540-8402 | Print ISSN : 2540-8399

representasi pengakomodiran perwakilan ormas-ormas keagamaan yang ada di daerah tersebut. Adapun landasan filosopis dari pengangkatan tersebut, bertujuan untuk menarik masyarakat (jamaah) menyimpan dananya di BPRS Harum Hikmahnugraha.Tentunya kedepan diharapkan aspek profesionalisme yang lebih dikedepankan dalam pengangkatan DPS di BPRS Harum Hikmahnugraha.

\section{Peran DPS Dalam Pelaksanaan GCG Di} BPRS Harum Hikmahnugraha

DPS BPRS Harum Hikmah nugraha berjumlah 3 (tiga) orang yang terdiri dari 1 (satu) orang ketua dan 2 (dua) orang anggota. Formasi DPS BPRS Harum Hikmah nugraha telah memenuhi syarat minimum jumlah keanggotaan yang ditetapkan oleh Bank Indonesia, yaitu minimal 2 (dua) orang dan maksimal $50 \%$ (lima puluh persen) dari jumlah Direksi.

\section{DPS BPRS Harum Hikmah} nugraha bersifat independen. Sebagian anggota DPS BPRS Harum Hikmah nugraha telah lulus uji kepatutan dan kelayakan (fit and proper test) Bank Indonesia tanggal 27-30 Juni $2010 \mathrm{M}$. Sebelum diangkat, sebagian anggota DPS BPRS Harum Hikmah nugraha telah memperoleh rekomendasi dari DSN-MUI. Namun untuk tahun 2013, karena ada pergantian dalam kepengurusan DPS, khusus untuk anggota DPS BPRS Harum Hikmahnugraha yang sekarang belum dilakukan uji kepatutan dan kelayakan oleh Bank Indonesia.

Komposisi, kriteria dan independensi DPS BPRS Harum Hikmahnugraha telah sesuai dengan PBI BUS/UUS maupun PBI GCG.Ketiga DPS Perseroan tidak memiliki hubungan keluarga, hubungankeuangan, hubungan kepengurusan, hubungan kepemilikan saham dengan anggota DPS lain, Dewan Komisaris dan Direksi, sehingga independen dalam menjalankantugasnya.

Dalam melaksanakan tugasnya DPS telah mengadakan rapat/pertemuan yang membahas perkembangan produk maupun aktivitas kegiatan operasional di BPRS Harum Hikmahnugraha.DPS telah mengadakan rapat dengan Direksi dan pejabat/karyawan senior BPRS Harum Hikmahnugraha sebanyak 3 (tiga) kali.Bahkan DPSBPRS Harum Hikmahnugraha merencanakan akan terus mengefektifkan rapat dengan seluruh anggota DPS minimal 1 (satu) bulan sekali. Tentu niatan ini menjadi langkah awal yang baik, guna memastikan operasionalisasi di BPRS Harum Hikmahnugraha memenuhi prinsip-prinsip syariah. Secara umum rapat diadakan dalam rangka mencari jalan keluar 
terhadap permasalahan akad dan shariah compliance yang dihadapi BPRS Harum Hikmahnugraha terkait penghimpunan dana masyarakat (dana pihak ketiga), penyaluran pembiayaan dan jasa bank secara umum yang belum diatur secara rinci di dalam Fatwa DSN-MUI.Hasil pertemuan DPS dengan pihak BPRS Harum Hikmahnugraha dituangkan dalam risalah rapat, selanjutnya menjadi rekomendasi dan opini syariah yang dipedomani pada operasional BPRS Harum Hikmahnugraha disamping Fatwa DSN-MUI, Peraturan Bank Indonesia dan ketentuan perundang-undangan lainnya. Secara berkala hasil rekomendasi DPS disampaikan kepada Direksi dan Dewan Komisaris BPRS Harum Hikmahnugraha.

Adapun tugas dan tanggung jawab DPS dalam pelaksanaanGCG di BPRSHarum Hikmahnugraha adalah; DPS merupakan badan independen yang bertugas melakukan pengarahan (directing), pemberian konsultasi (consulting) /nasihat dan atau saran, melakukan evaluasi (evaluating) dan pengawasan (supervising) kegiatan bank syariah dalam rangka memastikan bahwa kegiatan usaha bank syariah mematuhi (compliance) prinsip-prinsip syariah sebagaimana telah ditentukan oleh fatwa dan syariah Islam. Berdasarkan ketentuan yang tercantum dalam PBI
No.11/33/PBI/2009 tanggal 7 Desember 2009 tentang Pelaksanaan GCG bagi BUS dan UUS, disebutkan antara lain: 1). DPS wajib melaksanakan tugas dan tanggung jawab sesuai dengan prinsip-prinsip GCG; 2). Memberikan nasihat dan saran kepada Direksi serta mengawasi kegiatan bank agar sesuai dengan prinsip syariah; 2). Menilai dan memastikan pemenuhan prinsip syariah atas pedoman operasional dan produk yang dikeluarkan bank 3). Mengawasi proses pengembangan produk baru bank agar sesuai dengan fatwa DSNMUI; 4). Meminta fatwa kepada DSN MUI untuk produk baru bank yang belum ada fatwanya; 5).Melakukan review secara berkala atas pemenuhan prinsip syariah terhadap mekanisme penghimpunan dana dan penyaluran dana serta pelayanan jasa bank; 6). Meminta data dan informasi terkait aspek syariah dari satuan kerja bank dalam rangka pelaksanaan tugasnya.Dengan demikian maka DPS dituntut senantiasa memastikan seluruh transaksi di BPRS Harum Hikmahnugraha dijalankan sesuai dengan fatwa yang ditetapkan oleh Dewan Syariah Nasional serta dituntut senantiasa mengawasi kegiatan usaha bank dan memberikan opini mengenai kemurnian prinsip syariah yang dianut.

Hubungan kerja DPS, Dewan Komisaris dan Direksi adalah hubungan 
Amwaluna: Jurnal Ekonomi dan Keuangan Syariah Vol. 1 No.2 (Juli, 2017), 276-296

Online ISSN : 2540-8402 | Print ISSN : 2540-8399

checkand balance dengan tujuan akhir untuk kemajuan dan kesehatan BPRS Harum Hikmahnugraha serta pelaksanaan operasional BPRS Harum Hikmahnugraha yang sesuai dengan prinsip syariah dan senantiasa mematuhi (comply) peraturan dan perundang-undangan yang berlaku termasuk penerapan GCG.

Dalam melaksanakan fungsi dan tugasnya, Dewan Pengawas Syariah BPRS Harum Hikmahnugraha telah melakukan hal-hal sebagai berikut:

a. Sebagai mediator antara BPRS Harum Hikmahnugraha dengan DSN dalam mengkomunikasikan usul dan saran pengembangan produk dan jasa dari bank yang memerlukan kajian dan fatwa dari DSN;

b. Sebagai perwakilan DSN yang ditempatkan di BPRS Harum Hikmahnugraha, DPS wajib melaporkan atas hasil pengawasannya kepada DSN dan Bank Indonesia setiap 6 (enam) bulan sekali;

c. Pemberian opini dari aspek syariah terhadap pelaksanaan operasional BPRS Harum Hikmahnugraha secara keseluruhan dalam laporan publikasi BPRS Harum Hikmahnugraha;

Sebagai wujud pelaksanaan prinsip transparansi, anggota DPS BPRS Harum Hikmahnugraha juga telah mengungkap rangkap jabatan sesuai dengan PBI mengenai GCG.Seluruh anggota DPS Harum Hikmahnugraha tidak memiliki jabatan yang serupa di lembaga keuangan syariah lain, maupun menjadi konsultan di seluruh Bank Umum Syariah dan/atau Unit Usaha Syariah. Anggota DPS pun tidak memanfaatkan BPRS Harum Hikmahnugraha untuk kepentingan pribadi, keluarga dan/atau pihak lain yang mengurangi aset dan mengurangi keuntungan BPRS Harum Hikmahnugraha. Anggota DPS tidak mengambil dan/atau menerima keuntungan pribadi dari bank selain remunerasi dan fasilitas lainnya yang ditetapkan RUPS.

Sebagai bahan pertanggungjawaban (responsibility) pelaksanaan tugasnya di BPRS Harum Hikmahnugraha, DPS telah menyampaikan laporan pengawasan setiap 6 (enam) bulan kepada Bank Indonesia, yaitu disampaikan melalui surat No.017/HNN-DPS/I.2011 tanggal 11 Januari 2011 dan tanggal 12 Desember 2012. Laporan DPS dimaksud sesuai dengan surat Bank Indonesia No.12/1552/DPbS tanggal 24 September 2010 perihal laporan hasil pengawasan DPS BPRS Harum Hikmahnugraha, adapun uraiannya adalah sebagai berikut: 
Sesuaidenganprinsip pendirian

BPRS Harum Hikmahnugraha pada tahun 1994 yang bertujuan untuk mengembangkan produk jasa perbankan yang sesuai dengan prinsip syariah, maka PT.BPRS Harum Hikmahnugraha tetap konsisten dan terus berupaya istiqamah untuk menyempurnakan kegiatannya sesuai dengan prinsip syariah. Secara garis besar kegiatan yang dilakukan oleh BPRS Harum Hikmahnugraha ada 3 (tiga) bagian, diantaranya meliputi:

1. Penghimpunan Dana Pihak Ketiga

Produk yang dikembangkan oleh PT. BPRS Harum Hikmahnugaha sesuai dengan Undang-Undang Nomor 21 Tahun 2008 tentang perbankan syariah bahwa BPRS hanya menghimpun dana masyarakat dalam bentuk tabungan dengan akad mudharabah dan akad wadiah serta investasi deposito mudharabah yang berjangka 1, 3, 6, dan 12 bulan. Secara tekhnis penghimpunan tabungan baik yang berakad mudharabah maupun yang berakad wadiah dan investasi deposito telah memenuhi syarat sesuai dengan Fatwa DSN Nomor: 02/DSNMUI/IV/2000 tentang tabungan dan Fatwa DSN MUI Nomor 03/DSN-MUI/IV/2000 tentang deposito, juga telah sesuai dengan kodifikasi produk perbankan syariah yang dikeluarkan oleh Bank Indonesia.

2. Penyaluran Pembiayaan
Pembiayaan adalah penyediaan dana atau tagihan yang dipersamakan dengan itu berupa:transaksi bagi hasil dalam bentuk mudharabah dan musyarakah, transaksi sewa menyewa dalam bentuk ijarah atau sewa beli dalam bentuk ijarah muntahiya bittamlik, transaksi jual beli dalam bentuk piutang murabahah, salam dan istishna, transaksi pinjam meminjam dalam bentuk piutang qardh, transaksi sewa menyewa jasa dalam bentuk ijarah untuk transaksi multi jasa;

Berdasarkan persetujuan atau kesepakatan antara bank syariah dan pihak lain yang mewajibkan pihak yang dibiayai dan/atau yang diberi fasilitas dana untuk mengembalikan dana tersebut setelah jangka waktu tertentu dengan imbalan margin keuntungan, bagi hasil, biaya sewa, fee/ ujrah, dan/ atau tanpa imbalan.Dalam penyaluran pembiayaan, bank bertindak sebagai pemilik dana (shahibul mal) yang menyediakan dana dan nasabah berfungsi sebagai pengelola dana (mudharib) dalam kegiatan usahanya. Disisi lain bank mempunyai hak untuk melakukan pengawasan dan pembinaan usaha nasabah walaupun tidak ikut serta dalam pengelolaan usaha nasabah, antara lain bank dapat melakukan review dan meminta bukti-bukti dari laporan usaha nasabah berdasarkan bukti pendukung yang dapat dipertanggungjawabkan. 
Amwaluna: Jurnal Ekonomi dan Keuangan Syariah Vol. 1 No.2 (Juli, 2017), 276-296

Online ISSN : 2540-8402 | Print ISSN : 2540-8399

Pembagian hasil usaha dari pengelolaan dana dinyatakan dalam nisbah yang disepakati. Nisbah bagi hasil yang telah disepakati tidak boleh diubah sepanjang jangka waktu investasi, kecuali atas dasar kesepakatan para pihak.Jangka waktu pembiayaan atas dasar akad mudharabah, pengembalian dana dan pembagian hasil usaha ditentukan berdasarkan kesepakatan bank dan nasabah. Pembiayaan atas dasar akad mudharabah diberikan dalam bentuk uang dan/atau barang serta bukan dalam bentuk piutang atau tagihan.Dalam hal pembiayaan atas dasar akad mudharabah diberikan dalam bentuk uang harus dinyatakan secara jelas jumlahnya. Bila pembiayaan dengan akan mudharabah ini diberikan dalam bentuk barang, maka barang tersebut harus dinilai atas dasar harga pasar (net realizable value) dan dinyatakan jecara jelas jumlahnya.Pengembalian angsuran pembiayaan dilakukan dalam dua cara, yaitu secara angsuran ataupun secara sekaligus pada akhir periode akad sesuai dengan jangka waktu pembiayaan. Pembagian hasil usaha dilakukan atas dasar laporan hasil usaha pengelola dana dengan disertai bukti pendukung yang dapat dipertanggungjawabkan dan kerugian usaha nasabah pengelola dana (mudharib) yang dapat ditanggung oleh bank selaku pemilik dana adalah maksimal sebesar jumlah pembiayaan yang diberikan.Adapun manfaat dari pembiyaan ini merupakan diantara bentuk penyaluran dana pihak ketiga kepada nasabah produktif untuk mendapatkan bagi hasil sesuai dengan pendapatan usaha yang dikelola nasabah. Syarat dan tekhnis pembiayaan ini mengacu kepada Fatwa DSN-MUI Nomor: 07/DSN-MUI/IV/2000 tentang pembiayaan mudharabah.Untuk kegiatan yang dilakukan pada PT. BPRS Harum Hikmahnugraha adalah jenis kegiatan pembiayaan mudharabah, murabahah, qardh untuk rahn dan ijarah multi jasa.Semua pembiayaan ini sudah berjalan dari awal pendirian dan sesuai dengan yang difatwakan DSN-MUI.

3. Kegiatan Operasional

Dalam proses kegiatan operasional, PT. BPRS Harum Hikmahnugraha telah menggunakan Pedoman Akuntansi Perbankan Syariah Indonesia Nomor 59. Maka dalam penyusunan laporan keuangan baik untuk neraca, laporan laba rugi, maupun perubahan modal perseroan telah sesuai dengan PAPSI 2003, disamping itu juga telah menggunakan sumber dari PBI tentang penyusunan laporan keuangan BPR Syariah. 
Untuk mengarahkan kegiatan operasional agar sesuai dengan prinsip syariah, kami selaku DPS tidak saja melakukan pengawasan dalam bentuk telaah dokumen akad, tetapi juga hearing (dengar pendapat) langsung dari para karyawan atas permasalahan yang dihadapi.Kegiatan operasional PT. BPRS Harum Hikmahnugraha, ditilik dari SOP yang dikeluarkan, telah sesuai dengan prinsip syariah.Berdasarkan hasil pengamatan selama kegiatan operasional, PT. BPRS Harum Hikmahnugraha belum mengeluarkan produk baru yang belum ada fatwanya, sehingga tidak memberikan opini maupun usulan ke DSN-MUI.

Dari hasil pelaksanaan pengawasan yang dilakukan di BPRS Harum Hikmahnugraha selaku DPS, kegiatan yang dilakukan sebahagian besar sudah sesuai dengan prinsip syariah.Dibeberapa produk masih ada kelemahan-kelemahan dalam implementasi syariah, satu diantara contohnya masih ada potongan biaya administrasi yang masih menggunakan sistem prosentase.

Dalam melaksanakan tugas dan tanggung jawabnya, DPS telah memenuhi 5 (lima) prinsip GCG keterbukaan (transparency), akuntabilitas (accountability), pertanggungjawaban (responsibility), profesional (professional) dan kewajaran (fairness).Sementara itu pelaksanaan tugas dan tanggung jawab DPS untuk memastikan pemenuhan prinsip syariah (sharia compliance), bermula dari peran aktif DPS dalam proses pembuatan produk baru melalui pembahasan dan penyesuaian kebijakan dan prosedur produk terkait, sehingga secara keseluruhan memenuhi prinsip syariah. Proses ini diakhiri dengan opini kesesuaian syariah terhadap produk tersebut yang diterbitkan oleh DPS. DPS melakukan review kembali atas kebijakan dan prosedur guna melakukan penyempurnaan lebih lanjut apabila diperlukan.

Sesuai dengan fungsi pokoknya, DPS secara rutin memberikan saran dan nasehat kepada Direksi BPRS Harum Hikmahnugraha. Secara umum hal tersebut dilaksanakan melalui forum diskusi dalam rangka mencari jalan keluar terhadap skim produk yang belum diatur secara rinci dalam Fatwa DSN-MUI, terhadap permasalahan tersebut DPS memberikan opini dan rekomendasi syariah untuk dijadikan pedoman.

Pengawasan DPS berlanjut dengan melakukan review secara berkala terhadap operasional BPRS Harum Hikmahnugraha agar tidak menyimpang dari yang sudah ditetapkan dalam kebijakan dan prosedur yang telah ditetapkan dan ketentuan syariah lainnya. Pengawasan tidak terbatas 
Amwaluna: Jurnal Ekonomi dan Keuangan Syariah Vol. 1 No.2 (Juli, 2017), 276-296

Online ISSN : 2540-8402 | Print ISSN : 2540-8399

hanya di kantor pusat BPRS Harum Hikmahnugraha, DPS juga melakukan kunjungan ke kantor cabang/kas BPRS Harum Hikmahnugraha. Selain menjalankan fungsi pengawasan, DPS juga memberikan arahan kepada pegawai di kantor cabang/kas tentang mekanisme dan langkah-langkah yang harus dilaksanakan dalam rangka pemenuhan sharia compliance.Hasil pengawasan DPS dilaporkan kepada Bank Indonesia secara berkala setiap semester serta disampaikan pula kepada Direksi dan Dewan Komisaris sebagai rekomendasi.

Berdasarkan teori-teori yang telah dikemukakan sebelumnya dengan didukung hasil pengolahan data penelitian, penulis membuat sebuah hipotesis DPS merupakan pemain kunci yang khas dalam pelaksanaan GCG di bank syariah dalam rangka pemenuhan prinsip syariah.Oleh karena itu DPS sangat berperan dalam pelaksanaan good corporate governance di Bank Syariah (BPRS Harum Hikmahnugraha) terutama aspek pemenuhan prinsip syariah.

\section{Pengaruh Penerapan GCG di BPRS}

\section{Harum Hikmahnugraha Terhadap}

Tingkat Kepercayaan Masyarakat Pada BPRS Harum Hikmahnugraha

Tanggung jawab utama bank syariah adalah menciptakan kepercayaan bagi para deposan, serta meyakinkan bahwa operasionalnya telah sesuai dengan ketentuan syariah. Ketika para deposan menempatkan dana pada bank syariah, mereka dituntut diberikan pelayanan dan kepastian bahwa operasional bank telah berjalan sesuai dengan nilai-nilai syariah, dalam pengertian syariah tidak hanya dijadikan sebagai 'label' belaka untuk menarik minat deposan. Operasional bank, mulai dari penghimpunan dana sampai dengan penyaluran atau penggunaan dana pun harus patuh terhadap aturan syariah (Umer \& Ahmed, 2008).

Makna kepatuhan syariah dalam bank syariah adalah penerapan prinsip Islam, syariah, dan tradisinya ke dalam transaksi keuangan perbankan secara konsisten, dan menjadikan syariah sebagai kerangka kerja bagi sistem dan keuangan bank syariah dalam alokasi sumberdaya, manajemen, produksi, aktivitas pasar modal, dan distribusi kekayaan. Sehingga kepatuhan syariah dalam operasional bank meliputi produk, sistem, teknik, dan identitas perusahaan bukan hanya produk saja. Budaya perusahaan yang meliputi pakaian, dekorasi, dan imej perusahaan juga merupakan salah satu aspek kepatuhan syariah dalam bank syariah yang bertujuan untuk menciptakan suatu moralitas dan spiritualitas kolektif yang 
apabila digabungkan dengan produksi barang dan jasa akan menopang kemajuan dan pertumbuhan jalan hidup yang Islami.

(Cadbury, 2001) menegaskan bahwa oleh karena sifat kegiatan usaha bank yang menghimpun dana dari masyarakat dan disalurkan dalam berbagai bentuk kegiatan terutama pembiayaan dan investasi maka diperlukan suatu upaya perlindungan yang memadai agar fungsi penting untuk mendukung pembangunan ekonomi ini dapat berjalan dengan baik. Risiko yang dihadapi oleh bank mesti dipantau dengan suatu mekanisme check and balance yang memadai agar dapat menjaga kepercayaan pihak-pihak yang berkepentingan dengan fungsi perbankan. Hal yang terkait dengan mekanisme check and balance inilah yang menjadi fokus perhatian dari sistem corporate governance.

Menurut Mutamimah, penerapan GCG begitu penting, karena bank syariah merupakan lembaga intermediasi yang membutuhkan kepercayaan masyarakat dan seluruh stakeholders. Bank syariah mempunyai beberapa keunikan, yaitu: a) stakeholders yang lebih menyebar, b) informasi asimetrinya sangat tinggi, c) sulit memonitor serta mengakses kinerja dan risiko operasional bank syariah, d) mempunyai tingkat leverage yang tinggi, e) klaim bersifat jangka pendek dan rentan terhadap rush, dan f) tingkat regulasinya juga sangat tinggi. Oleh karena itu, bank syariah perlu menerapkan CGC, karena bisa mempengaruhi penilaian dan menurunkan cost of capital, mempengaruhi kinerja bank, reputasi bank, dan pengambilan risiko bank, serta meminimalisasi risiko krisis keuangan, baik untuk bank secara individual maupun bagi sistem bank secara keseluruhan.

Corporate governance yang baik merupakan langkah penting dalam membangun kepercayaan pasar (market confidence) dan mendorong arus investasi internasional yang lebih stabil, dan bersifat jangka panjang. Korporasi merupakan engine for wealth creation worldmide yang penting dan bagaimana perusahaan dijalankan akan mempengaruhi kesejahteraan dalam masyarakat secara keseluruhan. Agar dapat mencapai fungsi kemakmuran, perusahaan mesti beroperasi dalam suatu kerangka kerja yang mempertahankan perusahaan untuk fokus pada tujuannya dan akuntabel dalam tindakannya. Dengan kata lain perusahaan perlu menetapkan aturan tata kelola perusahaan yang memadai dan kredibel (Tunggal \& Tunggal, 2003).

Penerapan sistem GCG dalam perbankan syariah menurut Johan Arifin diharapkan dapat meningkatkan nilai tambah bagi semua pihak yang 
Amwaluna: Jurnal Ekonomi dan Keuangan Syariah Vol. 1 No.2 (Juli, 2017), 276-296

Online ISSN : 2540-8402 | Print ISSN : 2540-8399

berkepentingan (stakeholders) melalui beberapa tujuan berikut; 1).Meningkatkan efisiensi, efektifitas, dan kesinambungan suatu organisasi yang memberikan kontribusi kepada terciptanya kesejahteraan pemegang saham, pegawai dan stakeholders lainnya dan merupakan solusi yang elegan dalam menghadapi tantangan organisasi kedepan; 2).Meningkatkan legitimasi organisasi yang dikelola dengan terbuka, adil, dan dapat dipertanggung jawabkan; 3).Mengakui dan melindungi hak dan kewajiban para stakeholders; 4).Pendekatan yang terpadu berdasarkan kaidah-kaidah demokrasi, pengelolaan dan partisipasi organisasi secara legitimate; 5).Meminimalkan agency cost dengan mengendalikan konflik kepentingan yang mungkin timbul antara pihak prinsipal dengan agen; dan 6). Meminimalkan biaya modal dengan memberikan sinyal positif untuk para penyedia modal, meningkatkan nilai perusahaan yang dihasilkan dari biaya modal yang lebih rendah, dan meningkatkan kinerja keuangan dan persepsi yang lebih baik dari para stakeholders atas kinerja perusahaan di masa depan.

Dengan demikian melalui beberapa tujuan diatas, penerapan GCG pada bank syariah diharapkan: (1) semakin meningkatnya kepercayaan publik pada bank syariah, (2) pertumbuhan industri jasa keuangan Islam dan stabilitas sistem keuangan secara keseluruhan akan senantiasa terpelihara, dan (3) keberhasilan industri jasa keuangan Islam dalam menerapkan GCG akan menempatkan lembaga keuangan Islam pada level of playing field yang sejajar dengan lembaga keuangan internasional lainnya.

Berdasarkan pandangan-pandangan teori diatas ditambah hasil pengolahan data dan informasi dari responden penulis membuat sebuah hipotesis bahwa GCG berpengaruh terhadap tingkat kepercayaan nasabah pada bank syariah (BPRS Harum Hikmahnugraha).

Pada bagian ini, penulis akan mendiskusikan beberapa persoalan yang berhubungan dengan deposan dalam corporate governance. Salah satu persoalan penting yang menempatkan deposan sebagai 'principals' adalah seberapa baik bank menjalankan tugas penyimpanan dari 'agen' dalam hal menjalankan bisnis secara efisien dan sesuai dengan prinsip syariah. Para deposan dapat menggunakan disiplin pasar untuk meningkatkan pengelolaan bank dengan mengalihkan dana dari lembaga yang mempunyai kinerja buruk. Untuk melakukan hal ini, bagaimanapun deposan 
harus memahami karakteristik bank syariah dan mendapatkan cukup informasi tentang manajemen dan kinerja bank. Kemudian melaporkan karakteristik dasar dan preferensi deposan, pertanyaan tentang peran mereka sebagai stakeholders, pandangan mereka tentang bagaimana mereka mendapat informasi, reaksi mereka pada saat bank tidak berkinerja dengan baik ditambah dengan reaksi mereka pada saat bank tidak berkinerja sesuai dengan prinsip-prinsip syariah.

Berdasarkan keterangan pada data mengenai umur dan pendidikan dalam sampel. Umur rata-rata deposan adalah 30 tahun, usiamaksimal adalah dibawah 63 dan diatas 18 tahun. Pendidikan deposan mengindikasikan bahwa sebagian besar deposan memiliki pendidikan yang mendekati sama (merata). Deposan BPRS Harum Hikmahnugraha rata-rata Sekolah Menengah Atas (SMA).Pekerjaan deposan dalam sampel, penulis mencatat bahwa persentase deposan di BPRS Harum Hikmahnugraha terbesar adalah wirausaha75 \%, Pekerjaan deposan lainnya adalah petani $15 \%$, dan pegawai negeri serta pegawai swasta $5 \%$.Hubungan deposan dengan bank lain, 25 deposan (50 \%) menunjukkan bahwa mereka tidak memiliki rekening dibank lain. Sekitar 5 deposan $(5 \%)$ deposan memiliki rekening dibank syariah lainnya dan 20 deposan (45
$\%$ ) dari mereka memiliki rekening di bank konvensional.

\section{Tabel 1}

\section{Alasan Menggunakan BPR Syariah}

\begin{tabular}{|l|l|}
\hline Jumlah Responden & 50 \\
\hline Tidak berhubungan dengan riba & 25 \\
\hline Layanan yang baik & 23 \\
\hline Lainnya & 2 \\
\hline
\end{tabular}

Pertanyaan kepada para deposan tentang alasan mereka menggunakan BPRS Harum Hikmahnugraha, berdasarkan keterangan pada tabel diatas menunjukkan bahwa 25 responden (50\%) di BPRS Harum Hikmahnugraha memilih BPR Syariah dengan alasan untuk menghindari bunga (riba). Sebagian dari deposan juga 23 deposan (48\%) memilih BPR Syariah karena mereka mendapatkan layanan (service) yang baik, dan hanya 2 responden $(2 \%)$ menjawab lainnya.

\section{Tabel 2}

\section{Layanan Bank Syariah}

\section{Dibandingkan Bank Konvensional}

\begin{tabular}{|l|l|}
\hline Jumlah Responden & 50 \\
\hline Lebih baik & 48 \\
\hline Sama & 2 \\
\hline Lebih buruk & - \\
\hline
\end{tabular}

Berdasarkan keterangan pada tabel diatas menunjukkan betapa para deposan dalam sampel memberikan peringkat atas pelayanan BPR Syariah dibandingkan dengan bank lain hampir seluruh responden sebanyak 48 deposan (98\%) menilai layanan BPR Syariah lebih baik dari pada bank lain, 2 dari mereka (2\%) 
Amwaluna: Jurnal Ekonomi dan Keuangan Syariah Vol. 1 No.2 (Juli, 2017), 276-296

Online ISSN : 2540-8402 | Print ISSN : 2540-8399

menganggap sama, dan $0(0 \%)$ menilai lebih buruk.

Tabel 3

Pemahaman Deposan Terhadap Manajemen Bank dan Rekeningnya

\begin{tabular}{|l|c|c|c|}
\hline & Ya & Tidak & Total \\
\hline Melihat laporan tahunan & 15 & 35 & 50 \\
\hline Tahu bahwa bank memiliki DPS & 5 & 45 & 50 \\
\hline $\begin{array}{l}\text { Bisa mendapat informasi tingkat } \\
\text { keuntungan kapan saja }\end{array}$ & 5 & 45 & 50 \\
\hline $\begin{array}{l}\text { Disediakan laporan laba rugi } \\
\text { secara regular }\end{array}$ & 15 & 35 & 50 \\
\hline
\end{tabular}

Sebagaimana telah disebutkan, deposan dapat berperan penting dalam mendisiplinkan bank dengan menarik dana dari bank ketika mereka tidak menjaga fiduciary duties dengan baik dan pada saat mereka tidak berkinerja baik. Namun, untuk memainkan peran ini mereka tidak mendapatkan informasi tentang manajemen dan kinerja bank.Berdasarkan keterangan dari tabel diatas melaporkan tanggapan dari para deposan mengenai beberapa persoalan tersebut.Ketika ditanya apakah mereka melihat atau mengetahui laporan tahunan bank untuk memastikan kinerja bank, 35 responden $(70 \%)$ memberikan jawaban tidak. Pertanyaan yang lain ketika ditanya apakah mereka mendapatkan informasi mengenai tingkat keuntungan dari simpanan mereka di bank kapan saja mereka ingin, hampir seluruh responden 45 deposan $(90 \%)$ tidak mendapatkannya.

Supaya bank syariah beroperasi sesuai dengan prinsip-prinsip syariah, ditempatkan DPS di BPRS Harum Hikmahnugraha untuk memberikan pengarahan dan persetujuan atas aktivitas mereka.Hampir seluruh deposan, sebanyak 45 deposan (90 \%) tidak mengetahui bahwa ada DPS di BPRS Harum Hikmahnugraha, dan hanya 5 deposan (10 $\%)$ yang mengetahuinya.

Sekarang penulis akan melaporkan beberapa pertanyaan hipotesis yang mempunyai implikasi penting bagi $\mathrm{CG}$ bank. Hasil tersebut mengungkapkan peran deposan untuk meningkatkan pengelolaan bank melalui disiplin pasar. Jika bank gagal dalam kinerjanya dan tidak melaksanakan penyimpanan, maka para deposan akan menanggapinya dengan melakukan penarikan dana.

\section{Tabel 4}

Feedback Deposan Atas Isu Corporate Governance 


\begin{tabular}{|l|c|l|l|c|}
\hline & $\begin{array}{l}\text { Tetap } \\
\text { pada } \\
\text { bank } \\
\text { tersebut }\end{array}$ & $\begin{array}{l}\text { Pindah ke } \\
\text { bank } \\
\text { syariah } \\
\text { lain }\end{array}$ & $\begin{array}{l}\text { Pindah } \\
\text { ke } \\
\text { bank } \\
\text { lain }\end{array}$ & Total \\
\hline $\begin{array}{l}\text { Jika tahu bahwa BPR } \\
\text { Syariah tidak menjalankan } \\
\text { usahanya sesuai dengan } \\
\text { prinsip syariah }\end{array}$ & 3 & 3 & 44 & 50 \\
\hline $\begin{array}{l}\text { Jika tahu bahwa sebagian } \\
\text { keuntungan BPR Syariah } \\
\text { adalah dari bunga/riba }\end{array}$ & 5 & 5 & 40 & 50 \\
\hline $\begin{array}{l}\text { Jika ada rumor tentang } \\
\text { buruknya manajemen bank }\end{array}$ & 5 & - & 45 & 50 \\
\hline
\end{tabular}

Berdasarkan keterangan pada tabel diatas melaporkan reaksi yang mungkin dilakukan oleh deposan jika bank gagal dalam menjalankan tugas pokoknya, yaitu mengenai kesesuaian usaha bank dengan prinsip syariah. Jika deposan mengetahui bank tidak menjalankan usahanya sesuai dengan prinsip syariah, maka dalam persentase yang sangat besar sebanyak 44 deposan (90 \%) akan mengalihkan dananya ke bank lain. Hasil yang sama juga terlihat dari tanggapan deposan ketika ditanya apa reaksi mereka jika mengetahui sebagian pendapatan bank berasal dari bunga (riba). Jika hal tersebut terjadi, maka 40 deposan (90 \%), akan mengalihkan dananya ke bank lain.

Berdasarkan tabel diatas pun menunjukkan bahwa deposan akan memberikan hukuman pada BPR Syariah Harum Hikmahnugraha dengan menarik dananya jika ada rumor tentang buruknya kinerja bank. Jika rumor tersebut muncul, hampir seluruh deposan sebanyak 45 deposan (95 \%) akan mengalihkan dananya ke bank lain. Hasil ini mengindikasikan bahwa jika BPR Syariah tidak mempunyai kinerja yang baik dan tidak memberikan tingkat keuntungan yang kompetitif dengan pasar, maka mereka akan kehilangan deposannya.

Hasil penelitian terhadap nasabah BPRS Harum Hikmahnugraha menunjukkan bahwa deposan akan meninggalkan BPR Syariah jika BPR Syariah tidak beroperasi sesuai dengan prinsip syariah. Selanjutnya, rumor tentang buruknya kinerja bank syariah juga bisa menyebabkan adanya penarikan atau pengalihan dana. Untuk mempertahankan deposan, bank dituntut mempunyai kinerja yang baik, menghindari tindakan-tindakan yang bisa memunculkan rumor dan tetap patuh pada aturan atau prinsip syariah (sharia compliance).

\section{SIMPULAN}

Hal paling signifikan yang membedakan bank syariah dan bank konvensional adalah adanya kepastian pelaksanaan prinsip syariah dalam operasionalnya, untuk memastikan hal itu dibentuk DPS.Keberadaan DPS dalam struktur organisasi adalah wajib bagi lembaga keuangan yang beroperasi sesuai prinsip syariah. Pelanggaran syariah compliance yang dibiarkan DPS atau luput 
Amwaluna: Jurnal Ekonomi dan Keuangan Syariah Vol. 1 No.2 (Juli, 2017), 276-296

Online ISSN : 2540-8402 | Print ISSN : 2540-8399

dari pengawasan DPS, jelas akan merusak citra dan kredibilitas bank syariah di mata masyarakat, sehingga dapat menurunkan kepercayaan masyarakat pada bank syariah. Karena tanggung jawab utama bank syariah adalah menciptakan kepercayaan bagi para deposan, serta meyakinkan bahwa operasionalnya telah sesuai dengan ketentuan syariah. Operasional bank, mulai dari penghimpunan dana sampai dengan penyaluran atau penggunaan dana harus patuh pada prinsip syariah. Berdasarkan hasil analisis dan pembahasan dalam penelitian ini, maka dapat disimpulkan sebagai berikut :1)DPS sangat berperan dalam pelaksanaan GCG di BPRS Harum Hikmahnugraha terutama aspek pemenuhan prinsip syariah (sharia compliance). DPS adalah pihak yang memastikan dan mengawasi kesesuaian operasional dan produk bank terhadap prinsip syariah. 2)GCG terutama aspek kesesuaian dengan prinsip syariah (sharia compliance) di BPRS Harum Hikmahnugraha mempengaruhi terhadap tingkat kepercayaan masyarakat pada Bank Syariah/BPRS Harum Hikmahnugraha). Hal ini bisa dilihat dari reaksi deposan ketika mengetahui saat bank tidak berkinerja dengan baik dan berkinerja tidak sesuai dengan prinsip syariah, deposan akan mengalihkan dananya ke bank konvensional.

Adapun saran dalam penelitian ini, perlunya membangun suatu sistem CG yang efektif bagi bank syariah dengan memperhatikan sejumlah pilar mekanisme GCG, antara lain: 1). Peran dan tanggung jawab DPS mesti dioptimalkan untuk memberikan keyakinan bahwa seluruh transaksi yang dilakukan oleh bank tidak melanggar prinsip syariah; 2). Transformasi budaya korporasi yang Islami dan peningkatan kualitas SDM mesti menjadi komitmen bagi manajemen bank syariah, perangkat hukum dan peraturan Bank Indonesia dan Otoritas Jasa Keuangan yang sesuai dengan karakteristik bank syariah menjadi prasyarat guna terciptanya iklim pengawasan dan GCG yang sehat bagi bank syariah di Indonesia; 3). Dalam konteks syariah, auditor eksternal tidak saja berperan untuk memberikan opini bahwa laporan keuangan bank telah disajikan secara wajar sesuai dengan standar akuntansi yang berlaku. Auditor eksternal juga mesti bekerja sama dan mengkorelasikan pekerjaannya kepada DPS dan auditor internal untuk mendapat keyakinan bahwa penyajian laporan keuangan telah memiliki tingkat pengungkapkan dan transparansi yang 
memadai; 4). Bank syariah mesti memiliki sistem pengawasan internal dan manajemen risiko yang tangguh.Hal ini penting agar dapat mendeteksi dan menghindari terjadinya salah kelola dan penipuan maupun kegagalan sistem dan prosedur pada bank syariah.

\section{Daftar Pustaka}

A, C. (2010). Metode Penelitian Bisnis. Bandung: Alfabeta.

Agustianto, Optimalisasi Dewan Pengawas Syari'ah Perbankan Syariah.http://www.agustiantocentre.com/. Cadbury, A. (2001). Highlihts of the Proposal Of The Comitee On FinancialAspect of Corporate Governance In Prentice And Hollads. Oxford: Clarendon Press.

Effendi, Muh.Arif. (2009). The Power of Good Corporate Governance Teori Dan Implementasi. Jakarta: Penerbit Salemba Empat.

Husein Umar, (2008), "Metode Penelitian untuk Skripsi dan Tesis Bisnis", (Jakarta: Rajawali Press).

Ilyas, Nasirwan. (2006). Seputar Isu Corporate Governance dalam Bank Syariah, Buletin Hukum Perbankan dan Kebanksentaralan.Jakarta:www.bi.go.id

Khafid, M. (2012). Khafid, Muhammad. "Pengaruh tata kelola perusahaan (corporate governance) dan struktur kepemilikan terhadap persistensi laba. Jurnal Dinamika Akuntansi .
Mervin, K., Latifa, L., \& Al-Haod, M. (2005). Perbankan Syariah, Prinsip dan Prospek. Jakarta: PT. Serambi Ilmu Semesta.

Penjelasan Atas Peraturan Bank Indonesia Nomor 11/ 33 /PBI/2009 Tentang Pelaksanaan Good Corporate GovernanceBagi Bank Umum Syariah Dan Unit Usaha Syariah.

Peraturan Bank Indonesia Nomor 11/33/PBI/2009 Tentang Pelaksanaan Good Corporate Governance Bagi Bank Umum Syariah Dan Unit Usaha Syariah.

Pernyataan Standar Akuntansi Keuangan Akuntansi Perbankan Syariah. (2002) Jakarta: Dewan Standar Akuntansi Keuangan Ikatan Akuntan Indonesia

Promono, S. (2008). Corporate Governance In Islamic Banking, Critical issues And The Suitability Of Convensional Governance Mechanism. Jurnal Islamic Economics And finance, Vol 1 No 1 .

Puspitasari, E. (2009). Corporate Governance Lembaga Keuangan Islam Di Indonesia. Jurnal Dinamika Keuangan Dan Perbankan, Vol.1 No.1 Hal 10-17.

Tunggal, I. S., \& Tunggal, A. W. (2003). Memahami Konsep Corporate Governace. Yogyakarta: Balairung \& Co.

Umer, M. C., \& Ahmed, H. (2008). Coroprate Governance In islamic Financial ,Corporate Governance Lembaga Keuangan Syariah. Jakarta: Bumi Aksara.

Sugiyono. (2006). Metode Penelitian Kuantitatif, Kualitatif dan $R \& D$. Jakarta: CV. Alfabeta. 
Amwaluna: Jurnal Ekonomi dan Keuangan Syariah Vol. 1 No.2 (Juli, 2017), 276-296

Online ISSN : 2540-8402 | Print ISSN : 2540-8399

Surat Edaran Bank Indonesia Governancebagi Bank Umum Syariah dan No.12/13/DPbS/2010 Tentang Unit Usaha Syariah.

Pelaksanaan Good Corporate

Received : 2017-07-19 | Reviced : 2017-07-27 |Accepted: 2017-07-31 Indexed : DOAJ, Garuda, Crossref, Google Scholar | DOI : https://doi.org/10.29313/amwaluna.v1i2.2610 